\title{
Variations in Herbaceous Composition of Dry Tropics Following Anthropogenic Disturbed Environment
}

\author{
P.R. ORAON'1, LALJI SINGH and M.K. JHARIYA* \\ *Indira Gandhi Krishi Vishwavidyalaya, Raipur (C.G.) 492012, India. \\ 'Birsa Agriculture University, Ranchi (Jharkhand) 834006, India.
}

http://dx.doi.org/10.12944/CWE.9.3.50

(Received: May 24, 2014; Accepted: November 10, 2014)

\begin{abstract}
Present study was carried out at Bhoramdeo Wildlife Sanctuary of Chhattisgarh with the objective to assess the composition, structure and diversity of herb layer. Three circle of Kawardha forest division were selected, comprising of three disturbance gradients i.e., heavily disturbed, moderately disturbed and lightly disturbed site, respectively in each circle. Stratified random sampling was opted to measure the herbaceous vegetation. A total of 39, 39 and 33 herbs species were recorded under Bhoramdeo circle, Jamunpani circle and Salehwara circle, respectively. The total density of herbs was varied from 67800-146900 individuals ha-1 in Bhoramdeo circle, 70700-108700 individuals ha $^{-1}$ in Jamunpani circle and 72000-119200 individuals ha ${ }^{-1}$ in Salehwara circle. The diversity indices showed that Shannon index value for herb layer in different forest circle along the disturbance gradient varied from 2.50 to 4.25 , concentration of dominance $(\mathrm{Cd}) 0.06$ to 0.37 , species richness 1.35 to 2.19 , equitability 0.76 to 1.34 and beta diversity 1.44 to 2.44 . The experimental results clearly indicated that anthropogenic disturbances cause significant impact on ground flora in different circles.
\end{abstract}

Key words: Composition, Circle, Disturbances, Diversity indices, Herb.

\section{INTRODUCTION}

In many forest ecosystems, herbaceous vegetation is key strata and share to largest proportion of species diversity. The changes in herb layer occurred with topographic heterogeneity and biotic disturbances and harbor the majority of plant diversity in deciduous forests ecosystem ${ }^{1,2}$. Any kind of disturbances resulted to degradation of habitats, especially herbaceous vegetation, which is essential for regulating nutrient cycling as well as ecological balance. The herbaceous species are capable to modify the site conditions to some extent. The composition and luxuriance of ground vegetation in degraded ecosystem are mainly depends upon the secondary site conditions ${ }^{3}$. The composition of herbaceous layer is varied continuously in space and time due to multiple factors such as fire ${ }^{4}$ land use change, grazing, anthropogenic disturbances ${ }^{5}$, local weather, rainfall, moisture and soil fertility ${ }^{6}$.
Herbaceous vegetation is also affected by both natural and anthropogenic disturbances. Alteration in tree canopy due to tree falls, wildfire, harvesting, illicit felling are tends to moderate to large increases in resource availability ${ }^{7,8}$. However, disturbances in low severity usually cause little damage to overstorey trees ${ }^{9}$ but affect ground vegetation directly by shifting the habitat available resources ${ }^{10,11}$. The disturbances with high severity generate relatively homogeneous resource availability while low to moderate severity disturbances partially remove the canopy and generally result in greater resource heterogeneity ${ }^{12}$. Anthropogenic disturbances in forests followed by livestock grazing and forest fire adversely affected the composition of herbaceous vegetation ${ }^{13,14}$, it is therefore imperative to conserve the herbaceous vegetation of these sites. Hence, present study attempts to assess the composition and diversity of herbs following anthropogenic disturbance. 


\section{MATERIALS AND METHODS}

The present experiment was executed in the Bhoramdeo Wildlife Sanctuary, located in Kabirdham district. It occupies a special position from biodiversity and tourism point of view. The natural forest of Kawardha (Chhattisgarh) adjacent to Kanha National Park (M.P.) is one of the important natural heritage sites of Central India. It is well known for its rich, complex and diverse flora and fauna ${ }^{15}$. The study site is located between $21^{\circ} 23^{\prime}-22^{\circ} 00^{\prime}$ North latitude and $80^{\circ} 58^{\prime}-82^{\circ} 34^{\prime}$ East longitudes. The topography is hilly which falls in the Maikal Range of the Satpura hills. The altitude ranges from 600 to $900 \mathrm{~m}$ from the sea level and climate is dry tropical with annual average rainfall of $1250-1380 \mathrm{~mm}$. Different types of forest vegetation occur in the study area ${ }^{13}$. Northern and Eastern directions covered with luxuriant forests, whereas Teak plantations mainly occupy in Southern direction. The Western direction covered by degraded and mixed forest and also with bamboo brakes. The herbs widely found in this sanctuary are Achyranthus aspera inn., Apluda mutica Hack., Crotalaria calycina Schrank., Desmodium pulchellum (L) Benth., Eragrostis tenella Linn., Ischaemum pilosum Klein ex Willd., Paspalidium flavidum (Retz.) A.Camus, Tridax procumbens Linn. etc. ${ }^{15}$.

The study on herbaceous diversity along the disturbance gradient of tropical dry deciduous forest was done after the repeated reconnaissance survey of sanctuary area. Three circles viz., Bhoramdeo, Jamunpani and Salehwara were selected for the present study. In each of these circles, three disturbance gradients i.e., heavily, moderately and lightly disturbed site were identified following Kumar and Ram ${ }^{16}$. The herbaceous vegetation was measured within $1 \mathrm{~m} \times 1 \mathrm{~m}$ quadrat. The vegetational data were quantitatively analysed for frequency, density and abundance ${ }^{17}$. The importance value index was calculated followed Phillips ${ }^{18}$. Simpson index ${ }^{19}$ was used for concentration of dominance and Margalef index ${ }^{20}$ for species richness. Diversity indices were calculated following Sagar and Singh ${ }^{21}$. $\mathrm{A} / \mathrm{F}$ ratio (abundance to frequency) for different species was determined by eliciting the distribution pattern. The data was analysed in one-way analysis of variance. The significant differences between treatment means of all parameters were tested following Snedecor and Cochran ${ }^{22}$.

\section{RESULTS AND DISCUSSION}

\section{Bhoramdeo circle}

Herb density (Table 1) was maximum on heavily disturbed site and minimum on lightly disturbed site. The density of individual species were ranged from 200-86500 individuals ha-1 for heavily disturbed site, 600-40700 individuals ha $^{-1}$ for moderately disturbed site and 400-22400 individuals $\mathrm{ha}^{-1}$ for lightly disturbed site. Setaria spp. and Xanthium Strumarium showed highest frequency in highly disturbed site and Coriandrum sativum, Desmodium pulchellum, Lavandula bipinnata, Oscium gratissimum, Setaria spp. and Sida cordata in moderately disturbed site, whereas Coriandrum sativum, Imperata cylindrical, Ishaemum pilosum, Oscium gratissimum and Saccharum spontaneum in lightly disturbed site. Abundance to Frequency ratio (A/F) was ranged from 0.07 to 0.90 in highly disturbed site which indicated that most of the species were disturbed contagiously and randomly. In moderately disturbed site A/F value was 0.05 to 0.42 which revealed that most of the species performed contagious distribution pattern while a few species were distributed randomly. Under the lightly disturbed site $A / F$ ratio varied from 0.01 to 1.60 and showed that Asparagus resimosus only disturbed regularly on the site and rest of the species randomly and contagiously. The IVI values in Bhoramdeo circle across the disturbance gradient were ranged from 2.12-103.78. The dominant species of herbs on heavily disturbed was Setaria spp. Dominant species on moderately disturbed site was Lavandula bipinnata and on lightly disturbed site Saccharum spontaneum was the dominant species. Analysis of variance indicated that the three sites differed significantly in the herb density $(p<0.01)$. Along the disturbance gradient in Bhoramdeo circle the value of Shannon index ranged from 2.50-3.18, concentration of dominance from 0.16-0.37, species richness from 1.35-2.19, equitability value from $0.76-1.11$ and beta diversity from 1.44-2.44, respectively (Table 4).

\section{Jamunpani circle}

Under Jamunpani circle herb density was maximum in heavily disturbed site and minimum in 
ORAON et al., Curr. World Environ., Vol. 9(3), 967-979 (2014)

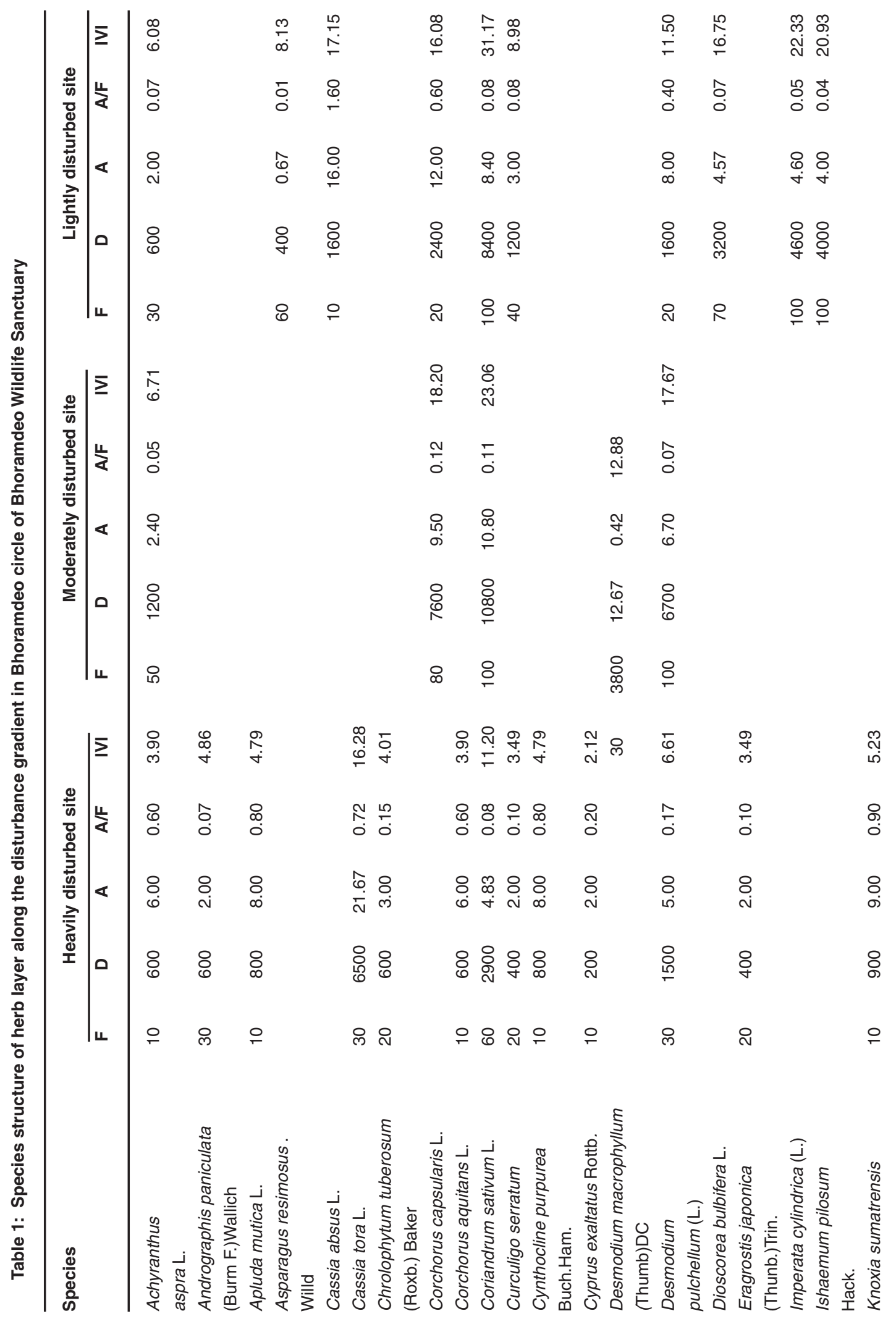




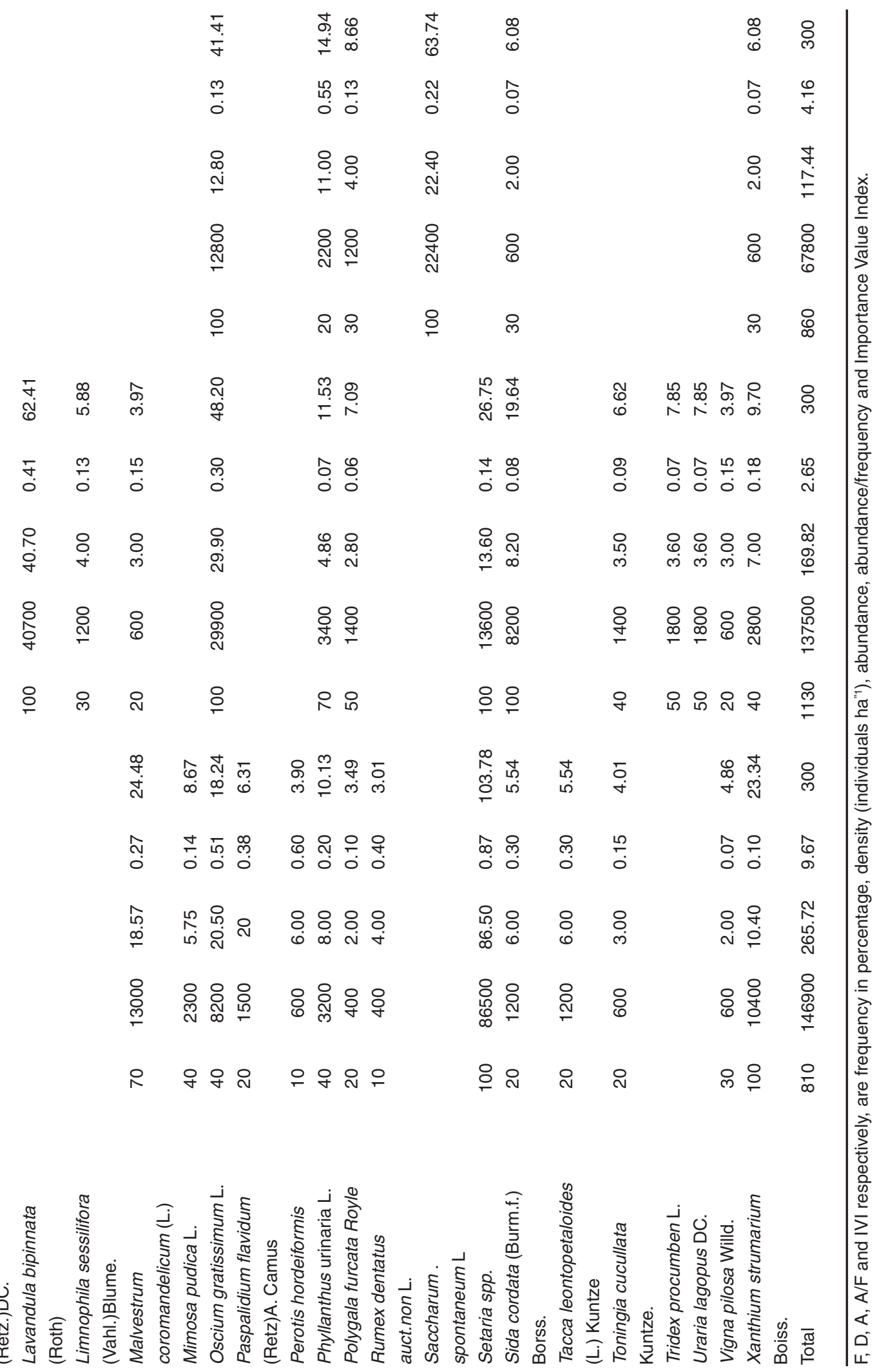


ORAON et al., Curr. World Environ., Vol. 9(3), 967-979 (2014)

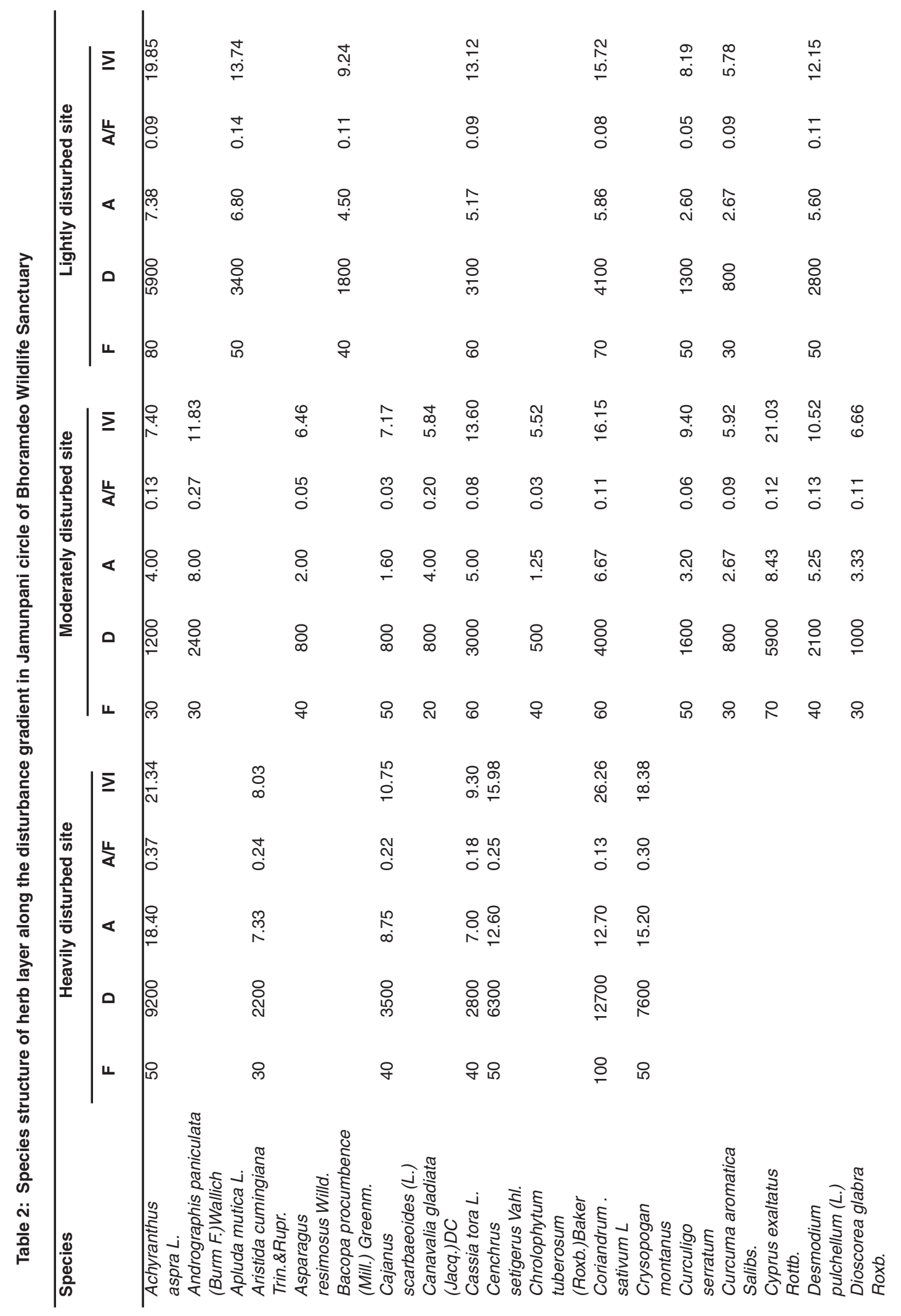


$\stackrel{\bar{N}}{\Gamma}$

$\stackrel{8}{\circ}$

$\stackrel{\infty}{\infty}$

\&্ল

8

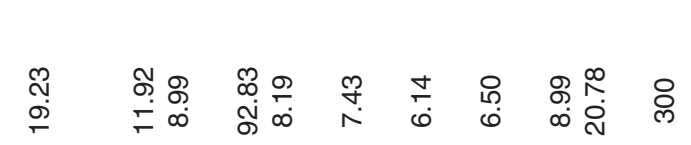
ஜํ. 융

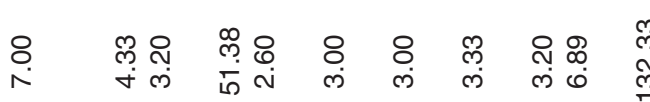
\&

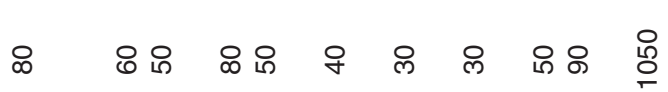

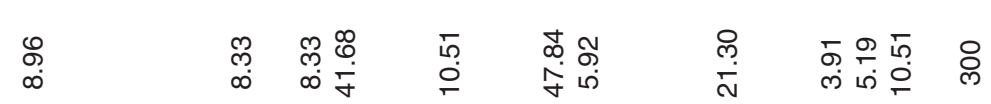

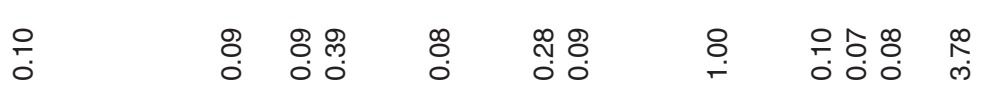

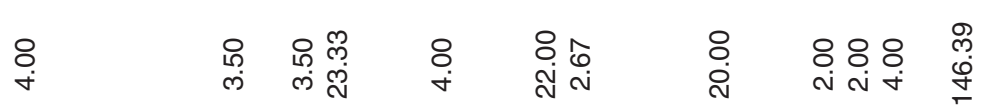

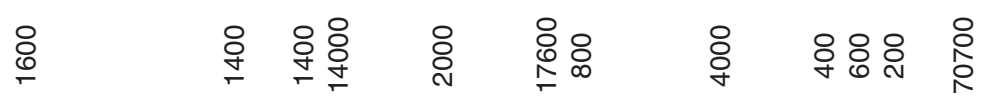

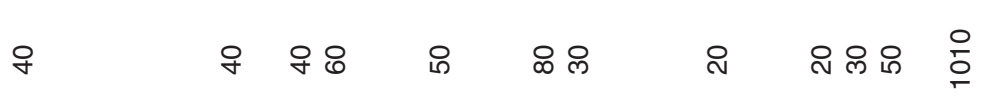

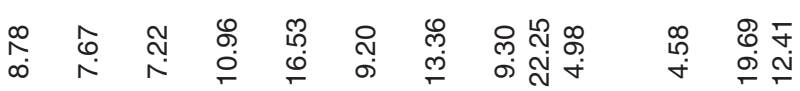

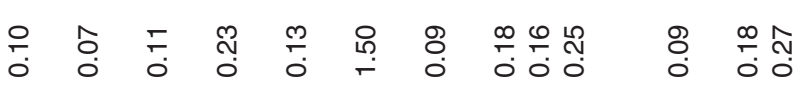

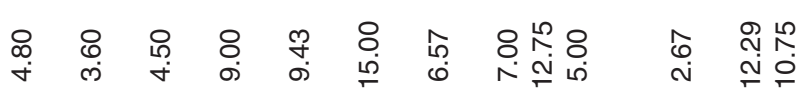
六 \&

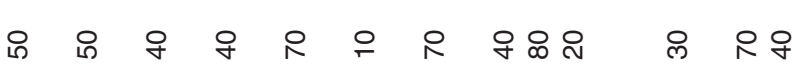

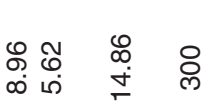
○: 㤂冬 ㅇํㅇำ 욷

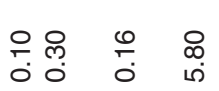

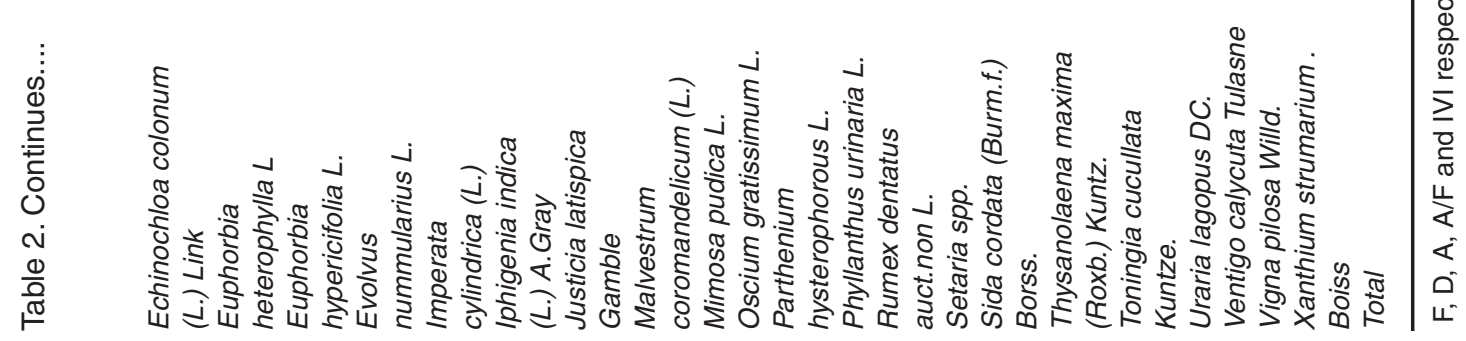




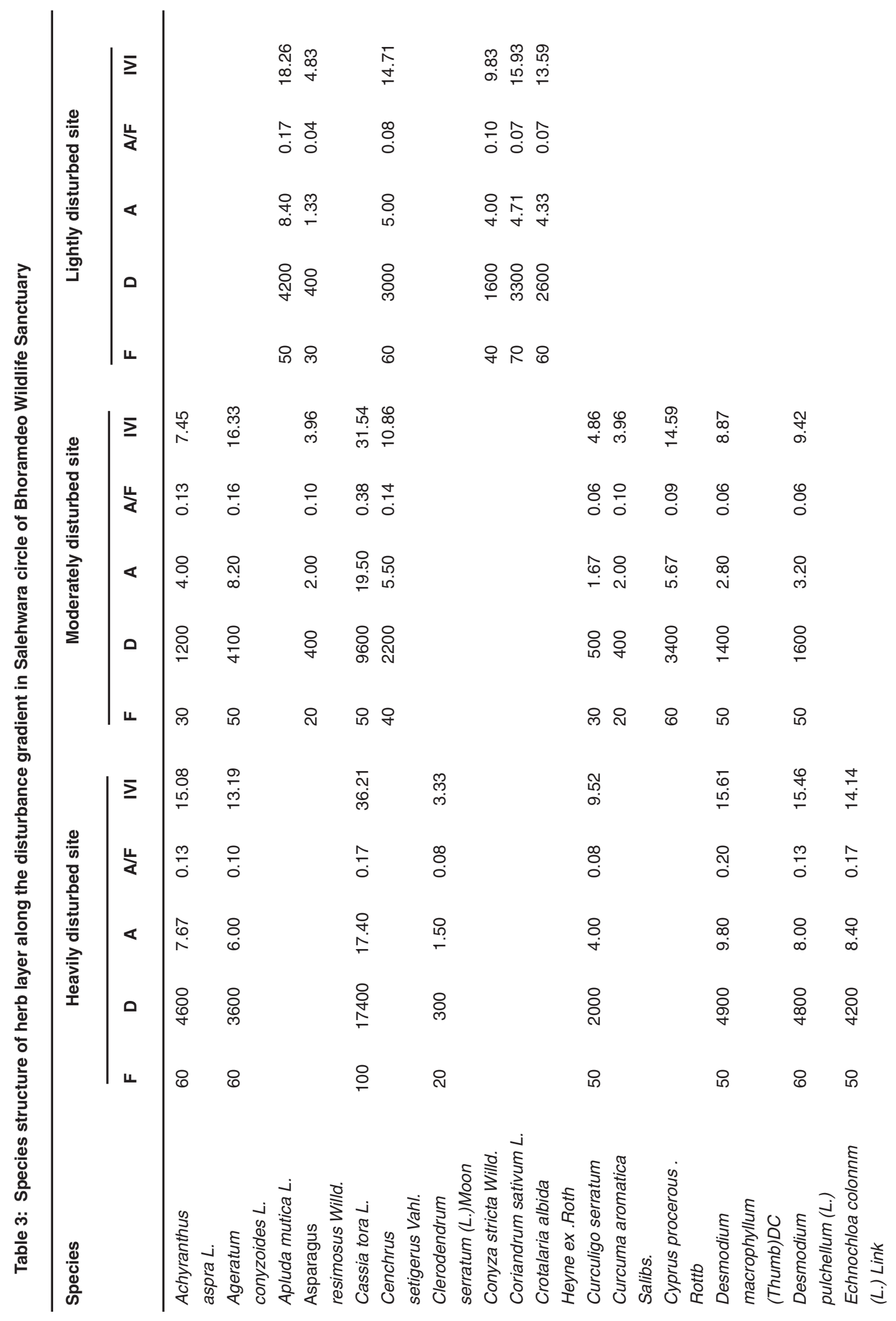




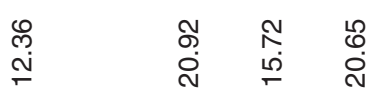

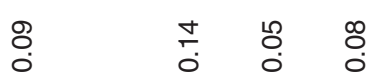

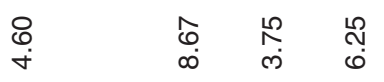

ষ্ల

요 8 ㅇ

$\begin{array}{ll}8 \\ \stackrel{8}{0} & \stackrel{+}{+}\end{array}$

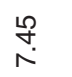

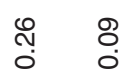

$\frac{m}{\circ}$

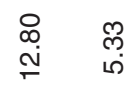

$\stackrel{8}{\circ}$

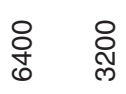

요 8

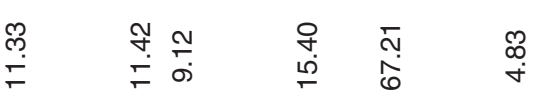

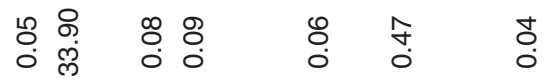

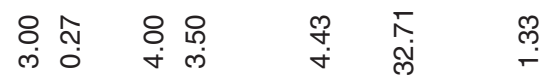

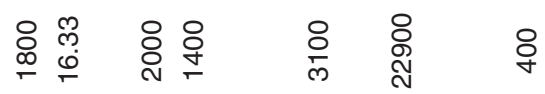

융 웅요 웅

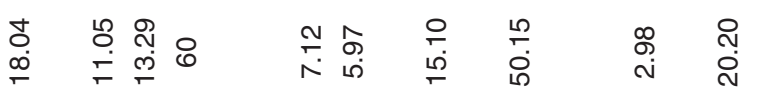

용

잉 웅 웅

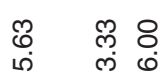

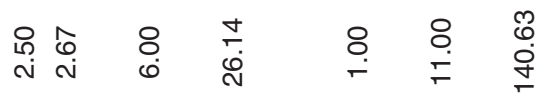

\& \& ㅇํㅇ

ঃ

우융 은

$\infty \quad 8$ 우

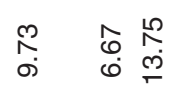

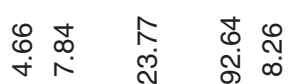

$\stackrel{\infty}{\circ} \stackrel{0}{0}$

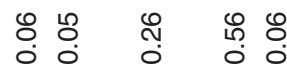

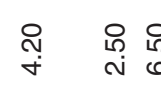

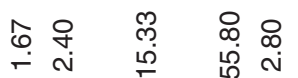

은

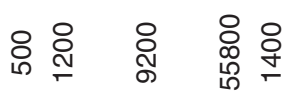

요 용

인요 으요
뭉요

৪্ল

$\stackrel{\circ}{\stackrel{\circ}{\leftarrow}}$

$\stackrel{\infty}{0}$
$\stackrel{0}{6}$

오

8ㅇ

\&্ల

过

요 8

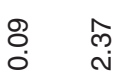

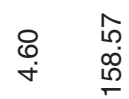

ষ্ল

요 웅

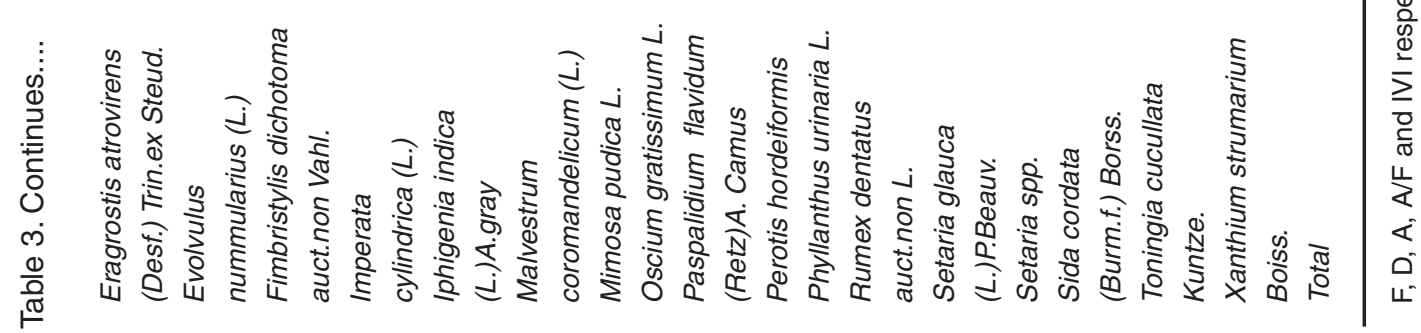


Table 4: Diversity pattern of herb layers along the disturbance gradient in forest circle of Bhoramdeo Wildlife Sanctuary

\begin{tabular}{lccccc}
\hline Circles & $\begin{array}{c}\text { Shannon } \\
\text { index (H') }\end{array}$ & $\begin{array}{c}\text { Simpson's } \\
\text { index (Cd) }\end{array}$ & $\begin{array}{c}\text { Species } \\
\text { richness (d) }\end{array}$ & $\begin{array}{c}\text { Equitability } \\
(\mathbf{( e )}\end{array}$ & $\begin{array}{c}\text { Beta } \\
\text { diversity }\end{array}$ \\
\hline Bhoramdeo & 2.50 & 0.37 & Heavily Disturbed Site \\
Jamunpani & 4.25 & 0.06 & 2.19 & 0.76 & 1.44 \\
Salehwara & 2.81 & 0.26 & 1.98 & 1.34 & 1.67 \\
& \multicolumn{7}{c}{ Moderately Disturbed Site } \\
Bhoramdeo & 3.18 & 0.16 & 1.44 & 1.10 & 1.94 \\
Jamunpani & 3.71 & 0.12 & 2.06 & 1.17 & 2.17 \\
Salehwara & 3.75 & 0.23 & 1.87 & 1.21 & 1.67 \\
Bhoramdeo & 3.08 & 0.17 & Lightly Disturbed Site & \\
Jamunpani & 3.08 & 0.24 & 1.35 & 1.11 & 2.44 \\
Salehwara & 3.40 & 0.15 & 1.43 & 1.05 & 2.11 \\
\hline
\end{tabular}

moderately disturbed site (Table 2). The density of individual species in highly disturbed site was 800 12700 individuals ha-1, 200-17600 individuals ha $^{-1}$ in moderately disturbed site and 800-41100 individuals ha $^{-1}$ in lightly disturbed site. The maximum frequency value was represented by Coriandrum sativum in highly disturbed site, by Setaria spp. in moderately disturbed site and Xanthium strumarium in lightly disturbed site. A/F value and IVI value in this circle across the disturbance gradient were ranged from 0.03 to 1.50 and 3.91 to 92.83 , respectively. The dominant species of herbs on heavily disturbed was Coriandrum sativum, Oscium gratissimum and Achyranthus aspra. Dominant species on moderately disturbed site was Setaria spp. and Oscium gratissimum. On lightly disturbed site Setaria spp. was the dominant species. Analysis of variance indicated that the three sites differed significantly $(p<0.05)$ in the herb density. The diversity indices in Jamunpani circle (Table 4) along the disturbance gradient shows that the value of Shannon index varied from 3.08-4.25, concentration of dominance 0.06-0.24, species richness 1.58-2.06, equitability 1.05-1.34 and beta diversity values from 1.672.11 .

\section{Salehwara circle}

In this circle the density of herb (Table 3 ) was maximum in heavily disturbed site and minimum in lightly disturbed site showing same trend as in
Bhoramdeo circle. The density of individual species were ranged from 300-55800 individuals ha-1 on heavily disturbed site, 200-18300 individuals ha $^{-1}$ on moderately disturbed site and $400-22900$ individuals ha ${ }^{-1}$ on lightly disturbed site. The highest frequency value is achieved by Cassia tora and Setaria spp. under highly disturbed site, Malvestrum coromandelicum under moderately disturbed site whereas in lightly disturbed site by Imperata cylindrica and Iphigenia indica, respectively. The value of $A / F$ ratio and IVI were ranged from 0.04 to 0.56 and 2.98 to 92.64 , respectively in this circle across the disturbance gradient. The dominant species of herbs on heavily disturbed was Setaria spp. and Cassia tora. Dominant species on moderately disturbed site was Setaria spp., Cassia tora and Eragrotis atrovirens. On lightly disturbed site Setaria spp., Paspalidium flavidum and Fimbrystylis dichotoma was the dominant species. Analysis of variance indicated that three sites differed significantly in herb density $(p<0.01)$. In Salehwara circle the value of Shannon index were ranged from 2.81-3.75, concentration of dominance from $0.15-0.26$, richness from 1.37-1.87, equitability from 0.99-1.21 and value of beta diversity from 1.50-1.94, respectively along the disturbance gradient (Table 4).

The floral and faunal communities in the ecosystems is largely influenced by the disturbances frequently occurring either by naturally or man- 
made $23,24,25$. In many of these systems, disturbances may alter the overall community structure ${ }^{26}$ which in turn affects the community and population dynamics. Herb layer composition is often interrelated with regional climate and site conditions ${ }^{27}$. Plants may assist other species directly by ameliorating severe environmental circumstances, changing substrate characteristics, or increasing the availability of a resource ${ }^{28}$. In the present study general structure of herbaceous species in all sites illustrated an increasing fashion as the disturbance rise. The reason for their maximum occurrence due to the availability of resources like space, light, moisture, nutrient and other environmental factors. Comparable to these Alhassan et al. ${ }^{29}$ reported similar aspects which are responsible for the variation in species recovery and diversity. The disturbed site supports more herbs as compared to least disturbed site due to reduction in competition for space and resources. The herb increases immediately due to the anthropogenic disturbance due to general reduction in tree cover that eventually supportive to growth and development of herbaceous vegetation due to availability of resources ${ }^{5,13,14,30,31}$.

In the present study the total herb density was varied from 67800-146900 individuals $\mathrm{ha}^{-1}$ on Bhoramdeo circle, $70700-108700$ individuals ha $^{-1}$ on Jamunpani circle and 72000-119200 individuals ha-1 on Salehwara circle. These figures are well within the range of herb density measured by Jhariya et al. ${ }^{13}$ (112000 to 668000 individuals ha ${ }^{-1}$ during pre-fire season whereas, 230000 to 510000 after fire season) and Jhariya et al..$^{5}$ (502000 to 724000 individuals $\mathrm{ha}^{-1}$ ). Pande ${ }^{32}$ studied the ecological status of vegetation in Satpura plateau (M.P.) and reported the total density of herb layer was 15905 to 102078 stems ha $^{-1}$. Negi and Nautiyal ${ }^{33}$ have found the 20-23 species of herbs in study area. Rastogi and Rastogi ${ }^{34}$ reported that the density of herbs varied between 168000-497800 per ha, which resemble with present estimated value.

Species diversity is known to be one of the key parameters typically describing the ecosystems and ecosystem functioning ${ }^{35}$. Worldwide, biodiversity is fluctuating at an unprecedented degree as a compound response to numerous biotic changes ${ }^{36}$. Species diversity tends to be low in physically controlled communities and high in biologically control communities ${ }^{3}$. The present estimated values of diversity indices were comparable with various studies. Rastogi and Rastogi ${ }^{34}$ found the diversity index between $0.918-0.967$, while the similarity index was between $33-80 \%$. Negi and Nautiyal ${ }^{33}$ reported the concentration of dominance (cd) was 0.1 to 0.13 , diversity index varied from 2.41 to 2.69 . Beta diversity between two sites of forests was 3.8 and 1.2 for herbs ${ }^{37}$. Pande ${ }^{38}$ showed the range of diversity index (Shannon Wiener index) as 0.642.34 and also described that diversity index was invariably higher for herbs and it was minimum for least disturbed sites. The species diversity ranged from 1.80 to 3.03 was also reported by Shameem et al. ${ }^{39}$ which are found to be similar with present study. Kittur et al. ${ }^{14}$ specified the diversity parameters of herb layer showed that Shannon index in different fire zones varied from 2.21 to 2.57 , equitability from 1.02 to 1.24 , species richness from 0.34 to 0.67 , concentration of dominance from 0.21 to 0.31 and beta diversity from 1.81 to 3.33 which are closer to similar with present outcomes. These parameters were also supported by the findings made by Jhariya et al. ${ }^{5,13}$. Analysis of variance calculated by Jhariya and Oraon $^{2}$ indicated that the dissimilarity in density among site were found significant at $p<0.05$ in both the fire season and the number of species was found significant in post-fire season $(p<0.05)$ which are line agreement with the present investigation.

$\mathrm{A} / \mathrm{F}$ ratio in present research indicated that most of the species showed contiguous and random distribution pattern while regular distribution found virtually insignificant on the Bhoramdeo Wildlife Sanctuary. Likewise, Jhariya et al.5,13; Jhariya and Oraon $^{2}$ and Kittur et al. ${ }^{14}$ described that most of the species documented in the investigated area follow the contagious and random distribution pattern whereas the regular distribution was negligible.

\section{CONCLUSION}

The improvement in vegetation cover is possible through systematic monitoring of livestock grazing and anthropogenic disturbance in these forest areas. Human disturbances have influenced the floristic composition at countless magnitude. Moreover, new sites need to be explored for seasonal grazing as substitute followed by protection for few years that certainly will allow the vegetation 
to regenerate which is constantly under threat due to various factors. However, increasing biotic interference at few sites need serious consideration and the human activities for fuel, fodder collection, harvesting of NTFPs, collecting medicinal plants or herbs, burning of the ground vegetation and uncontrolled livestock grazing requires sustainable management aspects or measures.

\section{REFERENCES}

1. Gilliam, F.S. and Roberts, M.R.: Conceptual framework for studies of the herbaceous layer. In: Gilliam FS, Roberts MR (eds) The herbaceous layer in forests of Eastern North America. Oxford University Press, Oxford, pp 3-11 (2003).

2. Jhariya, M.K. and Oraon, P.R.: Analysis of herbaceous diversity in fire affected areas of Bhoramdeo Wildlife Sanctuary, Chhattisgarh. The Bioscan, 7(2): 325-330 (2012b).

3. Bohre, P. Chaubey, O.P. and Singhal, P.K.: Bio-restoration and its Impact on Species Diversity and Biomass Accumulation of Ground Flora Community of Degraded Ecosystem of Coalmines. International Journal of Bio-Science and Bio-Technology, 4(4): 63-80 (2012).

4. Jhariya, M.K.: Impact of Fires on Forest Ecosystem: Vegetational Response to Forest Fire. Lap Lambert Academic Publishing. Heinrich-Bocking-Str. 6-8, 66121, Saarbrucken, Germany. 104 (2013).

5. Jhariya, M.K., Bargali, S.S., Swamy, S.L. and Oraon, P.R.: Herbaceous diversity in proposed mining area of Rowghat in Narayanpur District of Chhattisgarh, India. Journal of Plant Development Sciences, 5(4): 385-393 (2013).

6. Hutchinson, T.F., Boerner, R.E.J., Sutherland, S., Sutherland, E.K., Ortt, M. and Iverson, L.R.: Prescribed fire effects on the herbaceous layer of mixed-oak forests. Can J For Res, 35: 877-890 (2005).

7. Small, C.J. and McCarthy, B.C.: Spatial and temporal variation in the response of understory vegetation to disturbance in a Central Appalachian oak forest. J Torrey Bot Soc, 129: 136-153 (2002).

8. Roberts, M.R. and Gilliam, F.S.: Response of the herbaceous layer to disturbance in Eastern forests. In: Gilliam FS, Roberts MR (eds) The herbaceous layer in forests of eastern North America. Oxford University
Press, Oxford, pp 302-320 (2003).

9. Pawar, G.V., Singh, L., Jhariya, M.K. and Sahu, K.P.: Regeneration status in relation to anthropogenic disturbance in tropical deciduous forest of Chhattisgarh. The Ecoscan (Special Issue), 1: 281-285 (2012).

10. Elliott, K.J., Vose, J.M., Clinton, B.D. and Knoepp, J.D.: Effects of understory burning in a mesic mixed-oak forest in the Southern Appalachians. In: Engstrom, R.T., Galley, K.E.M., de Groot, W.J. (eds) Proceedings of the $22^{\text {nd }}$ tall timbers fire ecology conference: fire in temperate, boreal, and montane ecosystems. Tall Timbers Research Station, Tallahassee, pp 272-283 (2004).

11. Knoepp, J.D., Elliott, K.J., Vose, J.M. and Clinton, B.D.: Effects of prescribed fire in mixed-oak forests of the Southern Appalachians: forest floor, soil, and soil solution nitrogen responses. J Torrey Bot Soc, 136: 380-391(2009).

12. Gravel, D., Canham, C.D., Beaudet, M. and Messier, C.: Shade tolerance, canopy gaps and mechanisms of coexistence of forest trees. Oikos, 119: 475-484 (2010).

13. Jhariya, M.K., Bargali, S.S., Swamy, S.L. and Kittur, B.: Vegetational Structure, Diversity and Fuel Load in Fire Affected Areas of Tropical Dry Deciduous Forests in Chhattisgarh. Vegetos, 25(1): 210-224 (2012).

14. Kittur, B.H., Swamy, S.L., Bargali, S.S. and Jhariya, M.K.: Wildland Fires and Moist Deciduous Forests of Chhattisgarh, India: Divergent Component Assessment. Journal of Forestry Research, (DOI) 10.1007/s11676014-0471-0 (2014).

15. Jhariya, M.K., Bargali, S.S., Swamy, S.L., Kittur, B., Bargali, K. and Pawar, G.V.: Impact of forest fire on biomass and Carbon storage pattern of Tropical Deciduous Forests in Bhoramdeo Wildlife Sanctuary, Chhattisgarh. International Journal of Ecology and Environmental Sciences, 40(1): 57-74 
(2014).

16. Kumar, A. and Ram, J.: Anthropogenic disturbances and plant biodiversity in forests of Uttaranchal, Central Himalaya. Biodiversity and Conservation, 14: 309-331 (2005).

17. Curtis, J.T. and Mclntosh, R.P.: The interrelations of certain analytic and synthetic phytosociological characters. Ecology, 31: 434-455 (1950).

18. Phillips, E.A.: Methods of Vegetation Study. Holt R and Winston New York USA. pp. 105 (1959).

19. Simpson, E.H.: Measurement of diversity. Nature, 163: 688 (1949).

20. Margalef, R.: Perspective in ecological theory. University of Chicago Press, Chicago, (1958).

21. Sagar, R. and Singh, J.S.: Species diversity and its measurement. The Botanica, 49: 9-16 (1999).

22. Snedecor, G.W. and Cochran, W.G.: Statistical Methods. Oxford \& IBH Publ. Co., New Delhi, (1967).

23. Bennett, L.T. and Adams, A.: Assessment of ecological effects due to forest harvesting: approaches and statistical issues. J Appl Ecol, 41: 585-598 (2004).

24. Eldered, B.D. and Doak, D.F.: Comparing the direct and communitymediated effects of disturbance on plant population dynamics: flooding, herbivory and Mimulus guttatus. $J$ Ecol, 94: 656-669 (2006).

25. Kwit, C. and Platt, W.J.: Disturbance history influences regeneration of non-pioneer under storey trees. Ecology, 84(10): 2575-2578 (2003).

26. Shaforth, P.B., Stromberg, J.C. and Patten, D.T.: Riparian vegetation response to altered disturbance and stress regimes. Ecol Appl, 12: 107-123 (2002).

27. Small, C.J.: Environmental and Plant Biology Herb Layer Dynamics and Disturbance Response in the Mixed Mesophytic Forest Region of Southeastern Ohio. Ph.D. Thesis, pp. 176 (2001).

28. Joshi, B. and Bharti, M.C.: Temporal changes in facilitative effect of Coriaria nepalensis on growth of herbs on severely eroded hill slopes Central Himalaya. pp. 117-125. In: S.R. Gupta, N.K. Matta, A. Aggarwal, R.K. Kohli \& A.K.
Chawla (eds.) Ecology and Environmental Management: Issues and Research Needs. Bulletin of the National Institute of Ecology, New Delhi \& Jaipur, (2005).

29. Alhassan, A.B., Chiroma, A.M. and Kundiri, A.M.: Properties and classification of soils of Kajimaram oasis of Northeast Nigeria. Int $J$ Agric Biol, 8: 256-261 (2006).

30. Moretti, M., Zanini, M. and Conedera, M.: Faunistic and floristic post-fire succession in southern Switzerland: an integrated analysis with regard to fire frequency and time since the last fire. Forest Fire Research and Wildland Fire Safety, Viegas (ed.), ISBN 90-77017-72-0 (2002).

31. Keith, R.P., Thomas, T.V., Tania, L.S. and Rosemary, L.S.: Understory vegetation indicates historic fire regimes in ponderosa pine-dominated ecosystems in the Colorado Front Range. Journal of Vegetation Science, 21: 488-499 (2010).

32. Pande, P.K.: Biomass and productivity in some disturbed tropical dry deciduous teak forests of Satpura plateau, Madhya Pradesh. Tropical Ecology, 46(2): 229-239 (2005).

33. Negi, C.S. and Nautiyal, S.: Phytosociological studies of a traditional reserve forest -Thalke Dhar, Pithoragarh, Central Himalayas. Indian Forester, 13(4): 535 (2005).

34. Rastogi, N. and Rastogi, A.: Phytosociological analysis of the restored sal (Shorea robusta) plantations and natural sal forest of Tripura. Indian Journal of Forestry, 30(4): 377-385 (2007).

35. Scherer-Lorenzen, M., Korner, C. and Schulze, E.D.: Forest diversity and function: Temperate and boreal systems. Berlin, Springer. p. 399 (2005).

36. Hooper, D.U., Chapi, F.S., Ewel, J.J., Hector, A., Inchausti, P., Lavorel, S., Lawton, J.H., Lodge, D., Loreau, M., Naeem, M., Schmid, S.B., Setala, H., Symstad, A.J., Vandermeer, J. and Wardle, D.A.: Effects of biodiversity on ecosystem functioning: A consensus of current knowledge. Ecol Monogr, 75: 3-35 (2005).

37. Pande, P.K., Negi, J.D.S. and Sharma, S.L.: Plant species diversity composition. Gradient analysis and regeneration behaviour of some tree species in a moist temperate Western 
Himalayan forest ecosystem. Indian Forester, 128(8): 869-885 (2002).

38. Pande, P.K.: Comparative vegetation analysis and sal regeneration in relation to their disturbance magnitude in some sal forests. Tropical Ecology, 40(1): 51-61 (1999).
39. Shamem, S.A., Soni, P. and Bhat, G.A.: Comparative study of herb layer diversity in lower Dachigam National Park, Kashmir Himalaya, India. International Journal of Biodiversity and Conservation, 2(10): 308-315 (2010). 